\title{
Recent New Characterizations on the Giant Extracellular Hemoglobin of Glossoscolex paulistus and Some Other Giant Hemoglobins from Different Worms
}

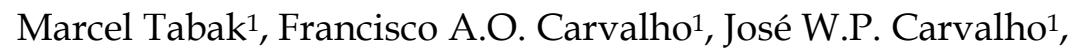 \\ Jose F.R. Bachega ${ }^{2}$ and Patrícia S. Santiago ${ }^{1,3}$ \\ ${ }^{1}$ Instituto de Química de São Carlos, Universidade de São Paulo, São Carlos, SP, \\ ${ }^{2}$ Instituto de Física de São Carlos, Universidade de São Paulo, São Carlos, SP, \\ ${ }^{3}$ Campus Experimental de Registro, UNESP, SP,
}

Brazil

\section{Introduction}

Giant extracellular hemoglobins, also known as erythrocruorins, have been investigated as a model of extreme complexity in oxygen-binding heme proteins [1,2]. They are characterized by a very high molecular mass $(M M)$ of several megadalton (MDa), and their oligomeric structure together with the crowded and protected heme environment are two of the main factors responsible for the high redox stability [3,4]. Superoxide dimustase (SOD)-like intrinsic activity, observed for hemoglobins of Lumbricus terrestris (HbLt) and of Arenicola marina $(\mathrm{HbAm})$, is another important factor [5,6]. These hemoglobins present a highly cooperative oxygen binding and a peculiar behavior associated to their oligomeric dissociation into smaller subunits and possible rearrangement back into the native oligomeric structure $[7,8]$.

Moreover, a strong motivation to study these giant hemoglobins is related to their potential use in medicine as blood substitutes. Studies have been performed in the past for HbLt [9], and are presently underway to test and validate the use of $\mathrm{HbAm}$ in this direction $[6,10]$. They seem to be very promising due to the lack of undesirable immunological reactions in tests with animals, explained by the absence of cell membranes as occurs with human hemoglobin in red blood cells [6,10]. Besides, the resistance to oxidation of extracellular hemoglobins, as noticed by their redox stability, is also an advantage as compared to the use of human hemoglobin in this medical application.

The giant extracellular hemoglobin of Glossoscolex paulistus (HbGp) is similar to several homologous proteins described in the literature [11-14]. These extracellular hemoglobins are constituted by a large number of globin-like subunits containing heme groups with $M M$ in the range $15-19 \mathrm{kDa}$. These globin subunits form monomers of $16 \mathrm{kDa}(d)$ and disulphide bound hetero-trimers of 51-52 kDa $(a b c)$, linked by non-heme structures (24-32 kDa), named linkers $(L)[12,13]$. Recent partial characterization of $M M$ of HbGp by matrix assisted laser 
desorption time-of-flight mass spectrometry (MALDI-TOF-MS) confirmed the similarity of its subunits to those of homologous proteins of this class, mentioned above, especially HbLt [15]. This characteristic multi-subunit content confers to the whole protein a double-layered hexagonal oligomeric structure. A common model for the quaternary structure, so-called "bracelet model", has been employed to explain the assembly of this class of proteins into their oligomeric structure.

It is worth of notice that HbGp belongs to the same class of hemoglobins as HbLt, which is one of the most studied hemoglobins in this group. Despite the fact that HbLt has been extensively studied over the past 20 years, the issue of its true $M M$ is still not fully understood. HbLt was one of the proteins studied by Theodore Svedberg and collaborators in 1933 [16], and later work by Daniel et al. has argued that the MM of HbLt could vary between 3.6 and 4.4 MDa [17]. They propose a model for the whole protein, consisting of twelve equal structures involving a dodecamer, $(a b c d)_{3}$, and three linkers $L_{3}$, together with twelve tetramers $(a b c d)$, in such a way that the protomer corresponding to the $1 / 12$ of the whole oligomer is given by $(a b c d)_{3} L_{3}(a b c d)$, or alternatively, $(a b c d)_{4} L_{3}[17,18]$. On the other hand, Vinogradov et al. [19] have proposed a model for HbLt, where 1/12 of the whole molecule is given by $(a b c d)_{3} L_{3}$, so that the difference between the two models is the presence of twelve additional tetramers in the former occupying the central part of the hexagonal bilayer.

Royer et al. describing the crystal structure of $\operatorname{HbLt}[11,20]$ has suggested that the Vinogradov model is very consistent with the crystal structure. Besides, very recent preliminary work on the crystal structure of HbGp [21] has also suggested a strong similarity between HbGp and HbLt, both belonging to class 1, where the two hexagonal layers forming the bilayer are rotated to 16 degree one relative to another. It is worthy of mention, that another extracellular hemoglobin from a sea worm, $\mathrm{HbAm}$, has also been investigated by Zal et al. [22,23]. In this case the structure belongs to class 2, where the two hexagonal layers are exactly eclipsed one relative to the other, as demonstrated in recent crystallographic studies at low resolution [24]. Besides, the assembly of the protomer corresponding to $1 / 12$ of the whole $\mathrm{HbAm}$ oligomer is different: a dodecamer formed by two monomeric units $\mathrm{a}_{1}$ and $\mathrm{a}_{2}$ together with a trimer $(T)$ gives $\left(a_{1}\right)_{3}\left(a_{2}\right)_{6} T$ associated to an average of 3.5 linkers resulting in a structure of $\left[\left(a_{1}\right)_{3}\left(a_{2}\right)_{6} T\right] L_{3.5}[23,25]$. This arrangement implies a different number of globin and linker chains for $\mathrm{HbAm}$. In this assembly the contacts between the subunits are quite different as compared to those in HbLt. Moreover, quite recently, the primary sequence of a fourth linker chain for HbLt has been reported, $\mathbf{L}_{4}$ [1]. The unanswered question remains as an open issue regarding the role of four linker chains in a structure that, apparently, only needs three of them. Another interesting question, relevant to the understanding of the overall oligomeric subunit stoichiometry, is the existence of several isoforms for some of the globin chains. This has also been elusive in the description of the crystal structure of the whole assembly at atomic resolution. So, the precise characterization of the several globin and linker subunits that constitute the native extracellular hemoglobins still remains a matter for further research.

In conclusion, this review chapter addresses the issue of the molecular masses of $\mathrm{HbGp}$ subunits, as monitored by sodium dodecyl sulfate polyacrylamide gel electrophoresis (SDSPAGE) and MALDI-TOF-MS, and their hydrodynamic properties, as monitored by analytical ultracentrifugation (AUC). Also new data from other three giant hemoglobins are 
added, to compare the differences and similarities between these systems: namely hemoglobins of Rhinodrilus alatus, Eisenia andrei and Perionyx excavatus. The focus of this study is the characterization of the different subunits that constitute each protein, aiming to assess in detail the nature of the subunit interactions that maintain the whole extraordinary oligomeric structure. These three new hemoglobins belong to different worm species that have been classified and studied previously only in relation to their biological effects upon the soil condition in their living habitat. Comparing the composition and structures of their subunits could be interesting also in relation to the understanding of the evolutionary changes evolved as a function of their different living environments. Finally, recent results concerning the subunits composition and architecture of $\mathrm{HbAm}$, in connection with its possible medical application as a blood substitute, are described.

\subsection{Some new extracellular hemoglobins from different worms}

The giant extracellular hemoglobins found in the Annelids, are characterized by high molecular mass and by an overall hexagonal symmetry [23]. Hemoglobin provides a fascinating example of molecular evolution. In this work four types of extracellular hemoglobins from different earthworms were studied.

These species of worms have very specific habitat and are found and live only in some restricted regions. It is not possible to produce some of these earthworm species in large amounts and captivity. Glossoscolex paulistus is a worm of the Glossoscolecidae family, very common and endemic in the cities of Piracicaba and Rio Claro, in state of São Paulo, Brazil [26]. The more common use of these earthworms is in the fishing, as baits. However, the extracellular hemoglobin of Glossoscolex paulistus, HbGp, has now been studied for more than twenty years, focusing its physical-chemical and structural properties, by several research groups in Brazil [27,28].

Rhinodrilus alatus is a species endemic and prevalent in sites in the regions of Sete Lagoas and Paraopeba, in the state of Minas Gerais, Brazil [29]. This species was considered to be threatened of extinction, due to its extensive use to achieve natural fertilizer as well as for bait in fishing. This species was well characterized and its anatomy is known [30], especially regarding the circulatory system. Rhinodrilus alatus is a giant earthworm, of 56 to $63 \mathrm{~cm}$ of length and 11 to $12 \mathrm{~mm}$ of diameter [30]. In the period of drought, between April and September, the earthworms of this species enter into spontaneous dormancy, in a camera protected by mucus. Rhinodrilus alatus belongs to the same family as the Glossoscolex paulistus worm. Differently from HbGp, the extracellular hemoglobin of Rhinodrilus alatus, $\mathrm{HbRa}$, is not known from the structural point of view.

Perionyx excavatus is a worm of the family Megascolecidae and genus Perionyx. Perionyx excavatus is an earthworm found commonly over a large area of tropical Asia although it has been transported to Europe and North America [31]. This is an endemic species which lives in organic wastes and high moisture contents, and adequate amounts of suitable organic material are required for populations to become fully established and for them to process organic wastes efficiently [32].

Perionyx excavatus had been shown to have efficient biological potential for conversion of organic wastes into high-value useful plant growth media [32]. Differently from the other two species, the Perionyx excavatus is produced in earthworm culture and its marketing is 
allowed around the world. For this reason, it is often used in the process of vermicomposting, which is a mesophilic process associated to ingestion, digestion, and absorption of organic waste carried out by earthworms followed by excretion of castings through the worm's metabolic system [32].

Another extracellular hemoglobin that is discussed in this work is collected from the annelid Eisenia andrei, HbEa. This is an earthworm of the family Lumbricidae and is known as the red California worm. This earthworm is between 5 to $10 \mathrm{~cm}$ in length and 4 to $8 \mathrm{~mm}$ in diameter, and it is the most used species in the world for decomposition of organic material [33]. The easy adaptation and reproduction of this species partly justify the Eisenia andrei large use around the world.

Some interesting studies suggest that earthworms can be used as biological indicators of soil contamination. Vampré et al. [34] showed that soil contamination by hexachlorobenzene (HCB) can be identified by analysis of soil and earthworm tissue extracts [34]. The earthworm has an important role in the equilibrium of the soil nutrients distribution, in particular, the increase of soil stability, infiltration rates, besides playing an important role in the phosphorus $(\mathrm{P})$ and nitrogen $(\mathrm{N})$ cycles [35]. In this context, interesting work has been developed by Brown et al. regarding the worms population of the state of Paraná, Brazil, aiming to evaluate the soil characteristics of this region [36].

\subsection{Extracellular worm hemoglobins as potential blood substitutes}

Giant extracellular hemoglobins are easily purified to a homogeneous product avoiding expensive synthetic steps. Besides, it is a product easy to store, the auto-oxidation is quite a slow process and it is less likely to cause immunogenic responses since cell membranes are not present and $\mathrm{HbAm}$, for instance, is not glycosilated [27]. Preliminary experiments have been performed many years ago with the naturally polymerized HbLt. Mice and rats undergoing exchange transfusion with $\mathrm{HbLt}$ revealed no apparent behavioral and physical changes [9]. A report on the potential use of $\mathrm{HbAm}$, showing that its structural and functional properties are consistent with the requirements for blood substitutes, has been published recently [6]. These properties should prevent kidney damage, reduce vasoconstrictor effect and oxygen radical formation, often associated with the administration of dissolved mammalian $\mathrm{Hb}$.

Structural analyses of $\mathrm{HbAm}$ under simulated human physiological conditions in vitro revealed its dissociation into high molecular weight and functional subunits, while in vivo experiments performed on mice revealed no apparent behavioral or physiopathological changes and absence of allergic response [6]. Recent effort has also been devoted to express some of the globin chains of $\mathrm{HbAm}$ considering the possibility of producing larger amounts of material aiming at reconstituting a recombinant hexagonal bilayer hemoglobin (HBL-Hb) by genetic engineering in order to provide a new oxygen carrier for therapeutic applications [10]. Considering the similarity of $\mathrm{HbGp}$ and $\mathrm{HbLt}$ with $\mathrm{HbAm}$ it is possible to conclude that all of them could be potentially useful for blood substitutes. Therefore, our studies aiming to obtain a deeper understanding of the structural and physical-chemical properties of HbGp and the new giant hemoglobins presented in this report can be quite relevant to a better evaluation of their potential biomedical applications. 


\section{Experimental methods}

In the present work, a review is presented of recent work performed in our laboratory, focusing on the molecular mass $M M$ of $\mathrm{HbGp}$, based on electrophoresis, AUC, and MALDITOF-MS [3,15]. SDS-PAGE electrophoresis is an extremely useful technique, especially to monitor the subunits contents present in different fractions of the protein obtained from gel exclusion chromatography [26]. Though this technique is not as precise as direct mass spectrometry, it is able to provide informations about the mass characteristic and migration properties of these subunits under the effect of an applied electric field at the same time.

X-Ray crystallography is a powerful structural technique, providing models of complex protein structures with atomic resolution [21].

\section{Results}

\subsection{Equilibrium of HbGp species obtained from alkaline dissociation at $\mathrm{pH} \mathbf{1 0}$}

Our recent $M M$ determination performed on two HbGp samples, at $\mathrm{pH} 7.0$, one in the reduced oxy- form, and the other in the oxidized cyanomet- form, have given values of $3.6 \pm$ $0.1 \mathrm{MDa}$ and $3.7 \pm 0.1 \mathrm{MDa}$, respectively [3]. This value is in excellent agreement with the prediction of the $M M$ for the whole molecule, based on the Vinogradov model, and our previous MALDI-TOF-MS analysis [15]: a tetramer $a b c d$ of $52.1+16.4=68.5 \mathrm{kDa}$ is observed, and assuming further an average $M M$ for the linkers of $28 \mathrm{kDa}$, plus 144 heme groups $(\sim 0.6$ $\mathrm{kDa}$ each), a total $M M$ of $12 \times[68.5 \times 3+28 \times 3]+144 \times 0.6=3560 \mathrm{kDa}$ is expected for $\mathrm{HbGp}$.

Very recent ultracentrifugation studies regarding the HbGp subunits, obtained from alkaline dissociation at $\mathrm{pH} 10$, provided further information on subunits masses, underlining the difficulties in separating, by simple SEC experiments, the linker chains from the trimer globin subunits due to their similar hydrodynamic properties [37]. In this study, analysis of the equilibrium dissociation of HbGp, at $\mathrm{pH} 10.0$, has shown that the whole protein is constituted by several species. For oxy-HbGp, at $\mathrm{pH} 10.0$, no contribution from un-dissociated whole protein is observed, suggesting that the reduced form is completely dissociated under this alkaline condition. However, for cyanomet-HbGp, $17 \%$ of the protein remains in the native un-dissociated form, implying a higher oligomeric stability of the oxidized cyanomet- form [37]. Results are shown in Tables 1 and 2 and can be summarized as follows: 1) AUC experiments for the monomer $d$ alone indicated that this species is quite pure. However, equilibrium is observed involving monomers and dimers of monomers. The dimer contribution is relatively low, around $10 \%$, similar to that observed in previous experiments by MALDI-TOF-MS, increasing at higher protein concentrations. 2) Analysis of oxy-HbGp solution, at $\mathrm{pH}$ 10.0, showed the existence of four species in equilibrium, assigned to the following subunits: monomer $d$, dimers of monomers $d_{2}$, trimers $a b c$ and a fourth species associated to the tetramer $a b c d$. The second species (dimers of monomers, $d_{2}$ ) revealed a significant intensity increase as compared to the pure monomer. This increase in intensity is, possibly, due to a superposition of the contribution from some linker chains, having masses near to the dimers of monomers $d_{2}$ one, around $32 \mathrm{kDa}$. Linker chains are characterized by mass values $M M$ in the range of $24-32 \mathrm{kDa}$, and are, probably, detected as a single peak, corresponding to the peak of the dimers of monomers. The third species, trimers $a b c$, is not observed for samples containing the reducing agent, $\beta$-mercaptoethanol, 
since the disulfide bonds are disrupted with the formation of the monomeric species that compose the trimers, monomers $a, b$ and $c$, consistent also with the increase in the contribution of the monomeric fraction, observed for this sample (Tables 1 and 2). Calculations of the sedimentation coefficients for the HbLt subunits based on the reported crystal structure $[11,20]$ gave additional useful informations for the interpretation of the obtained AUC data for HbGp: first of all, according to these estimates, the linker chains could appear together either with the monomeric globin chains or with the dimeric globins. Besides, the presence of linker chains associated to globin tetramers would not alter in significant ways the value of $\mathrm{s}$ for the pure globin tetramer.

\begin{tabular}{ccccccc}
\hline & & \multicolumn{5}{c}{ Observed species $^{\mathbf{c}}$} \\
\cline { 3 - 7 } Samples & $\mathbf{p H}$ & \multicolumn{5}{c}{$\boldsymbol{s}^{\mathbf{0}}{ }_{20, w}$} \\
\cline { 3 - 7 } & & $\mathbf{1}$ & $\mathbf{2}$ & $\mathbf{3}$ & $\mathbf{4}$ & $\mathbf{5}$ \\
\hline \multirow{2}{*}{ Monomer } & 7.0 & $2.05 \pm 0.05$ & $2.81 \pm 0.03$ & - & $5.7 \pm 0.1$ & \\
\cline { 2 - 7 } & 10.0 & $1.86 \pm 0.06$ & $2.9 \pm 0.5$ & - & $4.6 \pm 0.9$ & \\
\hline Oxy-HbGp & 10.0 & $1.7 \pm 0.1$ & $2.67 \pm 0.03$ & $4.12 \pm 0.06$ & $6.2 \pm 0.2$ & \\
\hline Oxy-HbGp & 10.0 & $1.64 \pm 0.06$ & $2.67 \pm 0.02$ & - & $4.6 \pm 0.2$ & \\
\hline $\begin{array}{c}\text { Cyanomet- } \\
\text { HbGp }\end{array}$ & 10.0 & $2.0 \pm 0.1$ & $3.06 \pm 0.09$ & $3.98 \pm 0.02$ & $6.6 \pm 0.2$ & $58.3 \pm 0.5$ \\
\hline
\end{tabular}

$\mathrm{Oxy}-\mathrm{HbG} \mathrm{p}^{1}-\mathrm{HbGp}$ in the presence of 2-mercaptoethanol. All data obtained at $236 \mathrm{~nm}$. ${ }^{\mathrm{a}} \mathrm{Observed}$ species 1, 2, 3, 4 and 5 correspond to pure monomer $d$, dimer of monomers $d_{2}$, trimer $(a b c)$, tetramer $(a b c d)$ and tetramer of monomers $d_{4}$ and un-dissociated cyanomet-HbGp, respectively.

Table 1. Sedimentation coefficients for the pure monomer $\boldsymbol{d}$, and for $\mathrm{HbGp}$, dissociated in alkaline medium, under the indicated conditions.

\begin{tabular}{ccccccc}
\hline \multirow{2}{*}{ Samples } & $\mathbf{p H}$ & \multicolumn{5}{c}{ Observed species $^{\mathbf{a}}$} \\
\cline { 3 - 7 } & & \multicolumn{5}{c}{$\mathbf{\%}$ (Area) } \\
\cline { 2 - 7 } & & $\mathbf{1}$ & $\mathbf{2}$ & $\mathbf{3}$ & $\mathbf{4}$ & $\mathbf{5}$ \\
\hline \multirow{2}{*}{ Monomer } & 7.0 & $84 \pm 8$ & $14 \pm 8$ & - & $2 \pm 1$ & - \\
\cline { 2 - 7 } & 10.0 & $89 \pm 4$ & $8 \pm 4$ & - & $3 \pm 1$ & - \\
\hline Oxy-HbGp & 10.0 & $24 \pm 8$ & $29 \pm 10$ & $38 \pm 3$ & $9 \pm 6$ & - \\
\hline Oxy-HbGp ${ }^{1}$ & 10.0 & $47 \pm 4$ & $38 \pm 3$ & - & $15 \pm 3$ & - \\
\hline $\begin{array}{c}\text { Cyanomet- } \\
\text { HbGp }\end{array}$ & 10.0 & $20 \pm 4$ & $20 \pm 7$ & $40 \pm 3$ & $3 \pm 1$ & $17 \pm 2$ \\
\hline
\end{tabular}

Oxy-HbGp 1 - HbGp in the presence of 2-mercaptoethanol. All data obtained at $236 \mathrm{~nm}$. ${ }^{\text {aThe species are }}$ the same described in Table 1.

Table 2. Percentage contributions of different species observed in the equilibrium of HbGp, dissociated at alkaline medium, $\mathrm{pH} 10.0$, and of monomer $d$, shown in Table 1. 
As mentioned above, for oxy-HbGp no contribution from un-dissociated protein was observed, implying that the reduced form is fully dissociated at $\mathrm{pH}$ 10.0. However, for cyanomet-HbGp, around $17 \%$ of un-dissociated protein remains in its native oligomeric form, consistent with a greater oligomeric stability for this oxidized form, in alkaline medium (Tables 1 and 2). Finally, equilibrium sedimentation data allowed an estimate of the masses $M M$ for the four globin chains, monomers $a, b, c$ and $d$. Due to the small difference of masses for monomers $b$ and $d$ they appear as a single unresolved peak in AUC and MALDITOF-MS [15] experiments.

\subsection{Initial characterization of the new extracellular hemoglobins from different worms}

In this section new data are presented regarding both electrophoretic and MALDI-TOF-MS measurements of HbGp subunits. Four linker chains are observed for this species by SDSPAGE, but with quite different concentrations that preclude their detection in the mass spectra experiments. Moreover, multiple chains were detected for the monomeric $c$ chain obtained by reduction of the trimer $a b c$, as for the isoforms of monomeric subunit $d$, reported earlier [15]. Together with the studies on HbGp, we have recently started to look at three different hemoglobins obtained from different worms, namely $\mathrm{HbRa}, \mathrm{HbPe}$, and $\mathrm{HbEa}$. Some preliminary results based on SDS-PAGE, AUC, and MALDI-TOF-MS studies are here reported for the first time, showing a great similarity, but not identity, among the subunit composition and masses for these extracellular hemoglobins as compared to HbGp.

\subsubsection{SDS-PAGE electrophoresis data}

In Figs.1A and 1B SDS-PAGE gels are shown for the extracellular hemoglobins of HbGp, $\mathrm{HbRa}, \mathrm{HbPe}$ and $\mathrm{HbEa}$, in the absence and the presence of 2-mercaptoethanol, respectively. The slot (S) corresponds to the standard masses used for calibration. The four hemoglobins in the present study showed a similar, but not identical, band pattern with mass values around $52 \pm 2 \mathrm{kDa}$, associated to the trimer subunit, and also very similar masses for the monomer $d$, around $12 \mathrm{kDa}$ (Fig.1A). The slots II and III correspond to HbGp. The slots IV and $\mathrm{V}$, corresponding to $\mathrm{HbRa}$, showed some differences as compared to $\mathrm{HbGp}$ : apparently two bands were observed in the trimer position, while the four linker subunits with different intensities were shifted as compared to HbGp bands. Furthermore, two linkers showed masses similar to those of HbGp and the other two smaller ones. The HbPe bands, shown in slots VI and VII, presented three linker chains, one of them with a higher mass as compared to $\mathrm{HbGp}$ and $\mathrm{HbRa}$ (mass value around $37 \pm 2 \mathrm{kDa}$ ). For the $\mathrm{HbEa}$ bands presented in slots from VIII to X, also three linker chains were observed, two of them with masses very close to those of $\mathrm{HbRa}$ and the third one with a greater one (around $49 \mathrm{kDa}$ ).

In Fig.1B a SDS-PAGE gel image is shown for the four different hemoglobins, in the presence of the 2-mercaptoethanol. The absence of the band corresponding to the trimer around $52 \mathrm{kDa}$ (see Fig.1A) was observed, as a result of the disulfide bond reduction into the three corresponding monomeric subunits. The linker pattern for HbGp and HbRa were essentially maintained upon addition of the reducing agent (slots II-III and IV-V, respectively). In the slots IV and V it was noticed that the monomeric subunits $\boldsymbol{a}, \boldsymbol{b}$ and $\boldsymbol{c}$ for $\mathrm{HbRa}$ were similar to those for HbGp. HbRa had two of these monomers with mass values very close, basically unresolved as a single broad band. HbPe, shown in slots VI and VII, presented one of the trimer monomeric subunits heavier than that for $\mathrm{HbGp}$ and $\mathrm{HbRa}$. 
However, the other two reduced monomeric subunits from the trimer were very similar, as observed for $\mathrm{HbGp}$ and $\mathrm{HbRa}$. The linkers pattern for $\mathrm{HbPe}$ changed upon disulfide bonds reduction in the presence of the 2-mercaptoethanol. It is not clear if this was only due to partial denaturation of the protein in the presence of the reducing agent, leading to a change in protein migration.
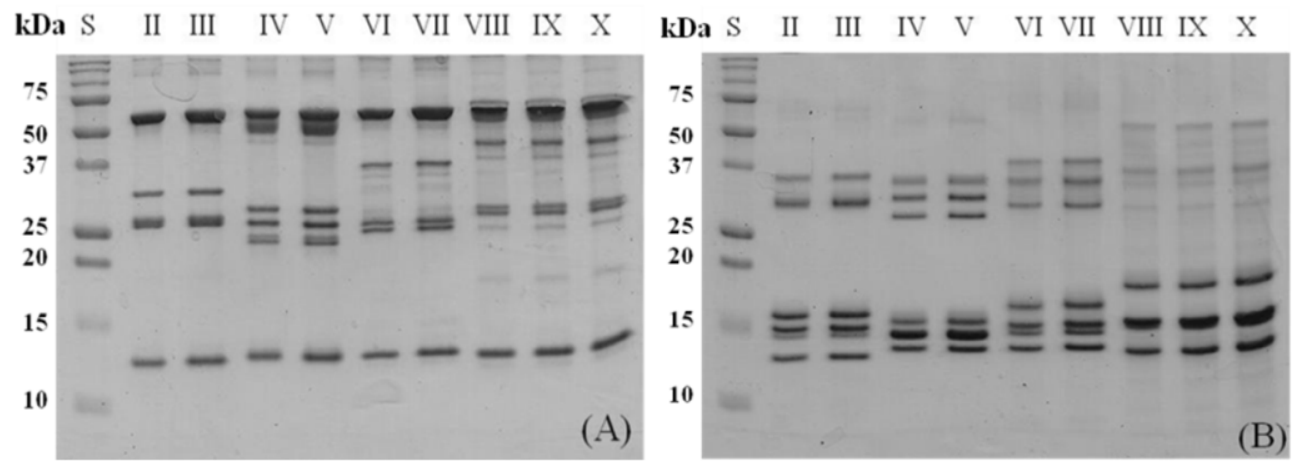

Fig. 1. SDS-PAGE gel electrophoresis for the different extracellular hemoglobins analyzed in this work. The gel concentration was $15 \%$ in $25 \mathrm{mmol} / \mathrm{L}$ Tris- $\mathrm{HCl}, 192 \mathrm{mmol} / \mathrm{L}$ glycine, $\mathrm{pH}$ 8.3, and stained with Comassie Blue R-250. The slot (S) corresponds to the standard masses. (A) Gel electrophoresis in the absence of 2-mercaptoethanol and (B) with the reducing agent. The slots II and III correspond to HbGp, slots IV and V to HbRa, VI and VII to HbPe, and VIII, IX and $\mathrm{X}$ to HbEa.

Based on SDS-PAGE, HbEa is the hemoglobin that presents subunits with the highest mass values. All the monomeric subunits obtained from the trimer are heavier as compared to the other hemoglobins studied in this work. Its monomeric subunits have mass values in the range from 12.5 to $18.5 \mathrm{kDa}$ (Fig. 1B). It is also observed one of the linkers with $M M$ of $47 \pm 2$ $\mathrm{kDa}$. These heavier subunits should confer a higher value of $M M$ to the whole $\mathrm{HbEa}$ as compared to $\mathrm{HbGp}, \mathrm{HbRa}$ and $\mathrm{HbPe}$. Although, some heavier chains are observed in $\mathrm{HbPe}$ and $\mathrm{HbEa}$, it seems that no stoichiometry change occurs for the whole oligomer as compared to $\mathrm{HbRa}$, since the same number of subunits is observed when the disulfide bonds are reduced: namely, four globin monomers and four linkers are detected. This implies that the hemoglobins $\mathrm{HbRa}, \mathrm{HbPe}$ and $\mathrm{HbEa}$ should have a stoichiometry for the whole protein of $\left[(\mathrm{abcd})_{3} \mathrm{~L}_{3}\right]_{12}$. Nevertheless, for HbGp only two linker chains are observed in the SDS-PAGE, but, probably, each observed band contains two linkers superposed or, alternatively, the amounts of two of the linkers are too low to be observed in the gel.

Interestingly, some differences observed in the migration for the monomeric subunits $d$ for all the studied hemoglobins, in the presence of the reducing agent 2-mercaptoethanol, can be associated to the higher unfolding of these subunits, due to the reduction of all disulfide bonds in the hemoglobins. For this reason, when the subunits undergo partial unfolding, their migration through the SDS-PAGE gel becomes more difficult. Being SDS-PAGE electrophoresis alone rather limited, more detailed characterization of the subunits for these hemoglobins by mass spectrometry was performed. 


\subsubsection{MALDI-TOF-MS data}

Fig.2 shows the MALDI-TOF-MS spectrum of a solution of hemoglobin of Rhinodrilus alatus, at $\mathrm{pH}$ 7.0, using sinapinic acid as matrix in positive ion mode. Fig. 2A shows the peaks obtained for the monomer $d$ subunit, the trimer $(a b c)$ and the linker chains. In agreement with previous studies of hemoglobin of Glossoscolex paulistus [15], Fig. 2A shows an intense peak centered around $16.3 \mathrm{kDa}$, corresponding to the monomer $d$, which is consistent with its relatively easy ionization. Fig.2B shows the expanded region from 15,500 to $18,200 \mathrm{Da}$, corresponding to the single protonation of the monomer $d$. The contribution of two more intense isoforms, $d_{1}$ and $d_{2}$, and another less intense isoform $d_{3}$ is evident in Fig.2B.
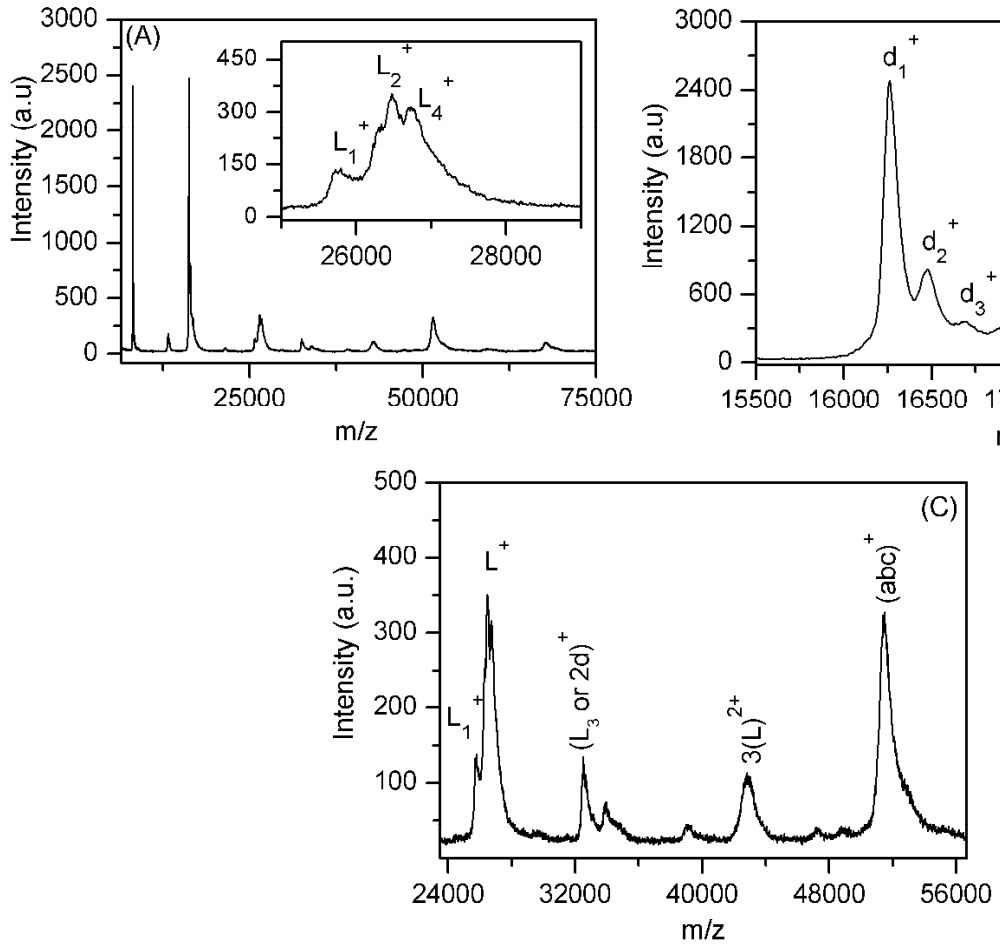

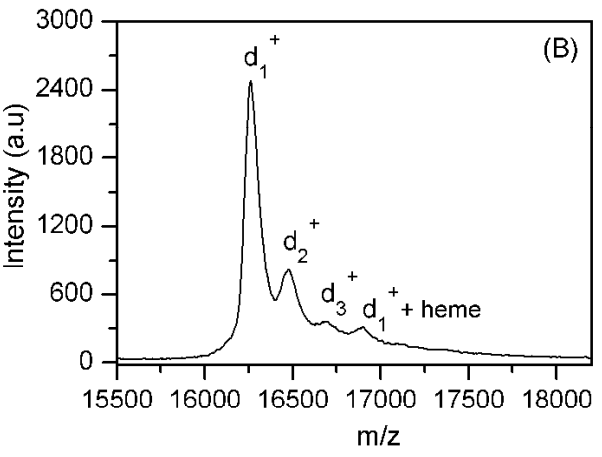

) 
can be superposed with the dimers of monomer $2 d$. Finally, an intense contribution at 51,470 $\mathrm{Da}$ is observed, associated to the trimer $(a b c)^{+}$, while the less intense species at $67,690 \mathrm{Da}$ is due to the contribution of the tetramer $(a b c d)^{+}($Table 3$)$.

Our results for HbRa suggest that the molecular masses of its subunits are very similar to those for HbGp, but the presence of two isoforms for the trimer subunit, as noticed for $\mathrm{HbGp}$ [15], is not observed in this hemoglobin. This might indicate that the monomers $a, b$ and $c$ do not have isoforms.

In Table 3, the results of analysis of MALDI-TOF-MS data for hemoglobin of Eisenia andrei are shown. In Fig. 3A the peaks obtained for the mono- and di-protonated monomer $d$ subunit are significantly more intense as compared to the trimer $(a b c)$ and the linker chains ones. The molecular mass of the monomer $d$ subunit is very similar to those for the HbGp and $\mathrm{HbRa}$ hemoglobins, but the peak corresponding to $d_{1}$ bound to the heme is not observed. In Fig.3B the three linker chains $L_{1}, L_{2}$ and $L_{4}$, with masses of 25,110, 26,470 and $27,445 \mathrm{Da}$, respectively, and another linker $L_{3}$ with a more intense peak at 32,775 $\mathrm{Da}$, are shown. Two additional contributions at 53,270 \pm 80 and 69,590 $\pm 100 \mathrm{Da}$ are also shown in Fig. 3C, which can be assigned to the trimer $(a b c)$ and tetramer $(a b c d)$, respectively. Differently from the $\mathrm{HbRa}$ and $\mathrm{HbGp}$, the hemoglobin of Eisenia andrei has only one predominant monomeric isoform $d_{1}$ with molecular mass at 16,344 $\pm 24 \mathrm{Da}$. The remaining monomeric isoforms have low intensities.

\begin{tabular}{ccccc}
\hline \multicolumn{5}{c}{ Mass of the extracellular hemoglobins in (Da) } \\
\hline Subunits & HbGp & HbRa & HbEa & HbPe \\
\hline$d_{1}$ & 16,370 & $16,272 \pm 16$ & $16,344 \pm 24$ & $16,220 \pm 19$ \\
$d_{2}$ & $16,415 \pm 10$ & $16,490 \pm 20$ & $16,495 \pm 12$ & $16,438 \pm 20$ \\
$d_{3}$ & $16,650 \pm 40$ & $16,710 \pm 25$ & 16,560 & $16,656 \pm 25$ \\
$d_{4}$ & $16,850 \pm 40$ & - & 16,790 & - \\
$d_{1}+$ heme & & $16,900 \pm 30$ & & $16,844 \pm 20$ \\
$L_{1}$ & $25,780 \pm 30$ & 25,770 & 25,110 & 25,670 \\
$L_{2}$ & $26,750 \pm 80$ & 26,540 & 26,470 & 27,145 \\
$L_{4}$ & - & 26,740 & 27,445 & - \\
$L_{3}$ or $2 d^{*}$ & 32,870 & 32,515 & 32,775 & 32,410 \\
$T_{1}$ (abc) & 51,200 & 51,470 & $53,270 \pm 80$ & 51,240 \\
$T_{2}$ (abc) & 51,985 & - & - & - \\
abcd & 68,400 & 67,690 & $69,590 \pm 100$ & 67,620 \\
\hline
\end{tabular}

*The value of mass corresponds very closely to the dimer of the monomer isoform $d_{2}$

Table 3. Molecular masses in (Da) of extracellular hemoglobin subunits, obtained from MALDI-TOF-MS, and for different worms. 

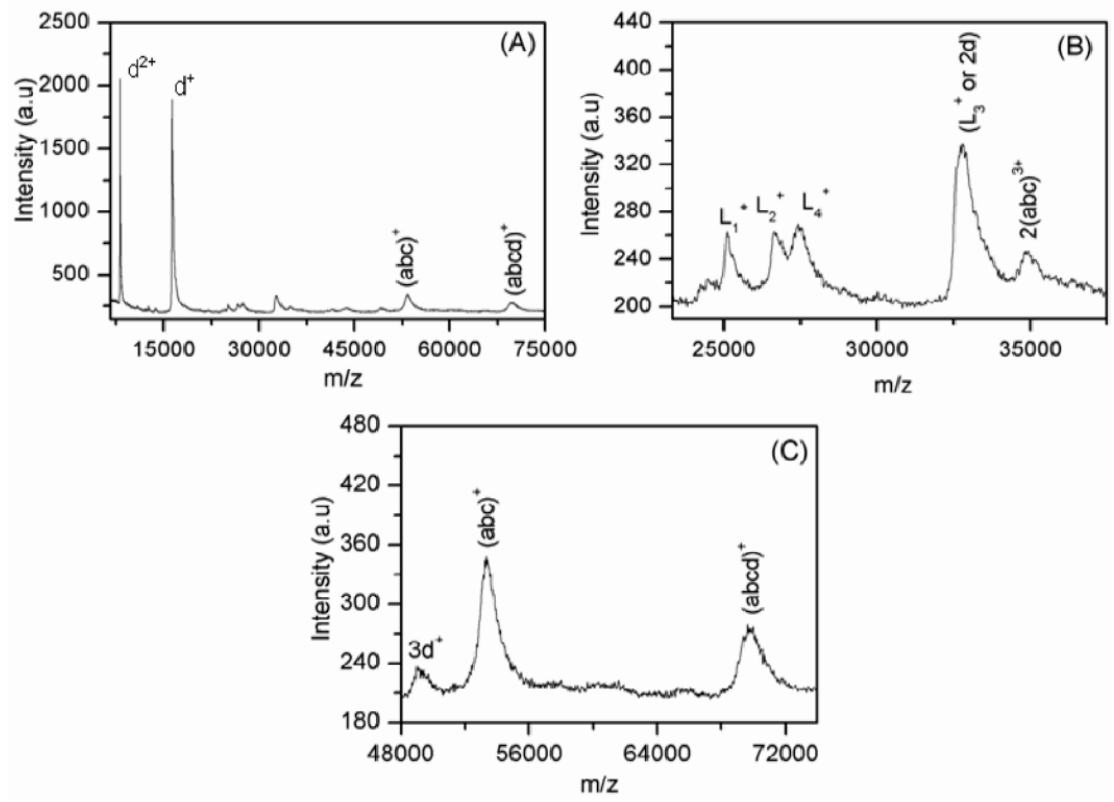

Fig. 3. MALDI-TOF-MS spectrum of Eisenia andrei hemoglobin, HbEa. (A) at pH 7.0, full mass range. (B) Corresponds to the intensity in arbitrary units, highlighting the linkers and triple-protonated dimer of trimer; $(\mathrm{C})$ the expanded region for the mono-protonated trimer $a b c^{+}$and tetramer $a b c d^{+}$from 48,000 to $75,000 \mathrm{Da}$.

Our results indicate that the HbEa presents two significant differences when compared with the HbGp: one of the monomeric chains $a, b$ or $c$, that constitute the trimer $a b c$, has a molecular mass higher than the corresponding $\mathrm{HbGp}$ one, due to the mass difference of 2 $\mathrm{kDa}$ observed in the trimer of the $\mathrm{HbEa}$ (Table 3). The second is the presence of one additional linker chain $\left(L_{4}\right)$ in the oligomeric structure of HbEa.

The data for hemoglobin of Perionyx excavatus are shown in Table 3 . In this case the molecular mass of monomer $d$ is analogous to that observed for the other hemoglobins. Moreover, it was noticed that a small proportion of the monomer $d$ remained associated to heme with a mass of $16,844 \pm 20 \mathrm{Da}$. In general, the subunits of the $\mathrm{HbPe}$ are very similar to those of $\mathrm{HbGp}$, since no significant differences in the molecular masses are observed. Very recent studies of $\mathrm{HbGp}$, in the presence of 2-mercaptoethanol [38], have shown that the monomer $c$ chain presents also four isoforms with $M M$ in the range of 17.3-17.6 kDa. This is, probably, why the trimer $T$ is also characterized by two isoforms (Table 3). Further experiments in the future, in the presence of 2-mercaptoethanol will be necessary to elucidate more clearly the masses differences of the globin subunits forming the trimer $a b c$, especially regarding the new hemoglobins.

\subsubsection{AUC data}

All AUC experiments were performed in $100 \mathrm{mmol} / \mathrm{L}$ Tris- $\mathrm{HCl}$ containing $50 \mathrm{mmol} / \mathrm{L}$ $\mathrm{NaCl}$, at $\mathrm{pH} 7.0$ or 5.0 , and at $20^{\circ} \mathrm{C}$. The protein concentrations were in the range 100 to 300 
$\mu \mathrm{g} / \mathrm{mL}$, and the speed rotor was 20,000 rpm. The SEDFIT software was used in the analysis of sedimentation velocity (SV) data. The $\mathrm{V}_{\text {bar }}$ parameter used in the fits was the standard value of $0.733 \mathrm{~mL} / \mathrm{g}$ and $f / f_{0}$ was allowed to float being a regularization parameter.

Fig.4 shows sedimentation coefficient distributions c(S), at $200 \mu \mathrm{g} / \mathrm{mL}$, for the four extracellular hemoglobins. Our results indicate that three of the four hemoglobins present a good homogeneity with a single species in solution. However, for the extracellular hemoglobin of Eisenia andrei two different populations are observed, the first one around 10 $\mathrm{S}$ can be associated to the dodecamer subunits while the other species at $64 \mathrm{~S}$ corresponds to the whole protein. Although these proteins are quite stable in these conditions [3], the observed dissociation is, probably, due to the purification process used for this hemoglobin.

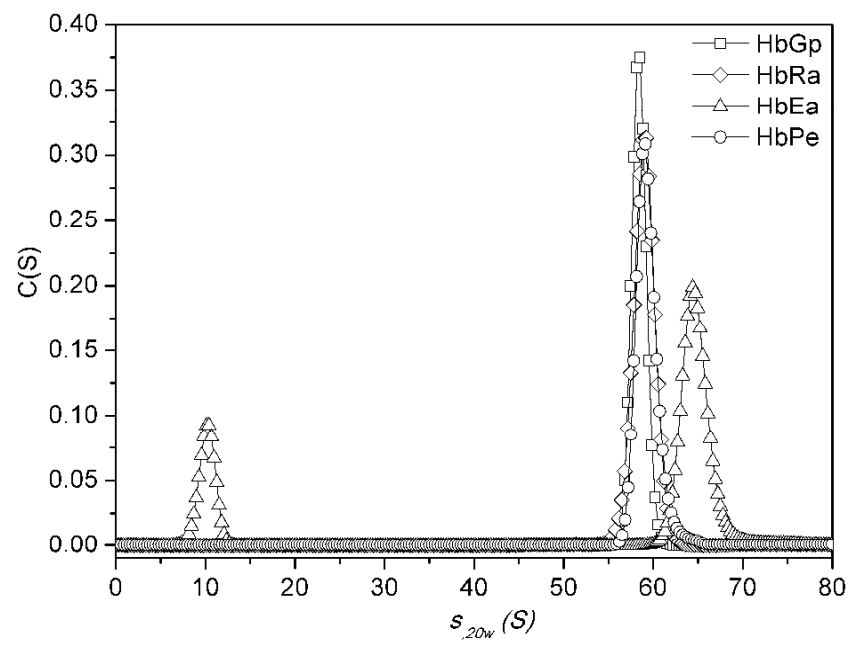

Fig. 4. Continuous sedimentation coefficient distribution of extracellular hemoglobins. The c(S) fittings for hemoglobins, at a concentration of $200 \mu \mathrm{g} / \mathrm{mL}$, in $100 \mathrm{mmol} / \mathrm{L}$ Tris- $\mathrm{HCl}$ containing $50 \mathrm{mmol} / \mathrm{L} \mathrm{NaCl}$, are shown. The s,20w for each fitted curve was determined as the maximum of the peaks of $\mathrm{c}(\mathrm{S})$ curves. Absorbance was monitored at $415 \mathrm{~nm}$.

The work of Krebs et al [39] on the properties of the dodecamer subunit, $(a b c d)_{3}$, of HbLt showed that the dodecamer obtained from urea dissociation of the whole protein consisted of an equilibrium of three species with sedimentation coefficients of 8.5 - 9.4 S, 3.6 - 4.4 S and $1.9 \mathrm{~S}$. According to our AUC data for $\mathrm{HbGp}$, the dodecamer is associated to the $8.5-9.4 \mathrm{~S}$ species. The other two species correspond to trimers and monomers, in order of decreasing $s$, implying that urea dissociation in $\mathrm{HbLt}$ [39] produces an equilibrium of three species.

The $s$ values were corrected to standard conditions (water and $20{ }^{\circ} \mathrm{C}$ ), and the $s^{0} 20, w$ values, corresponding to $s_{20, w}$ at $0 \mathrm{mg} / \mathrm{mL}$ protein, were obtained by linear regression extrapolation. The $s_{20, w}$, values for the oxy-HbGp at $\mathrm{pH} 5.0$ and 7.0 were $58.6 \pm 0.4$ and $58.1 \pm 0.4 \mathrm{~S}$, respectively, as shown in Table 4. These results suggest that HbGp is very stable in both $\mathrm{pH}$ values, and does not undergo oligomeric dissociation at $\mathrm{pH}$ 5.0. For the other two hemoglobins, $\mathrm{HbRa}$ (Rhinodrilus alatus) and $\mathrm{HbPe}$ (Perionyx excavatus), similar results were observed as for $\mathrm{HbGp}$ [3], with $s^{0}{ }_{20, w}$ around of $59 \mathrm{~S}$. The mass values are very similar, within the experimental error, with the exception of $\mathrm{HbEa}$ that has a higher mass (Table 4). 


\begin{tabular}{lcc}
\hline \multicolumn{1}{c}{ Hemoglobins } & $s_{20, w}^{0}(S)$ & MM by c $(M)$ (kDa) \\
\hline Glossoscolex paulistus $(\mathrm{HbGp})^{1}$ & $58.6 \pm 0.4$ & $3600 \pm 80$ \\
Glossoscolex paulistus $(\mathrm{HbGp})^{2}$ & $58.1 \pm 0.4$ & $3500 \pm 100$ \\
Rhinodrilus alatus $(\mathrm{HbRa})$ & $59.1 \pm 0.1$ & $3500 \pm 70$ \\
Eisenia andrei $(\mathrm{HbEa})$ & $64.6 \pm 0.4$ & $3850 \pm 50$ \\
Perionyx excavatus $(\mathrm{HbPe})$ & $58.9 \pm 0.2$ & $3500 \pm 50$ \\
\hline
\end{tabular}

${ }^{1} \mathrm{HbGp}$ at $\mathrm{pH}$ 5.0. ${ }^{2} \mathrm{HbGp}$ at $\mathrm{pH} 7.0$.

Table 4. AUC hydrodynamic data analysis, for extracellular hemoglobins from different worms, at $20.0 \pm 0.1{ }^{\circ} \mathrm{C}$ and $\mathrm{pH} 7.0$.

In Fig.5 the $\mathrm{c}(\mathrm{M})$ distributions are shown for the four types of studied extracellular hemoglobins, at a protein concentration of $300 \mu \mathrm{g} / \mathrm{mL}$. It is noticed that $\mathrm{HbEa}$ has a higher $M M$ than the other three hemoglobins one (Table 4). This $330 \mathrm{kDa}$ difference can be attributed to two factors: 1) the difference of the subunits masses constituting the oligomeric structure, and 2) a different subunit stoichiometry for the HbEa oligomer. Thus, the inclusion of another linker chain in the structure of $\mathrm{HbEa}$, giving a model like $\left[(a b c d)_{3} L_{4}\right]_{12}$, could contribute with a $326 \mathrm{kDa}$ increase in the total mass of the molecule, consistent with the results observed for $\mathrm{HbEa}$ in the $\mathrm{c}(\mathrm{M})$ values. This fourth linker chain would have an average mass of $326 / 12=27 \mathrm{kDa}$.

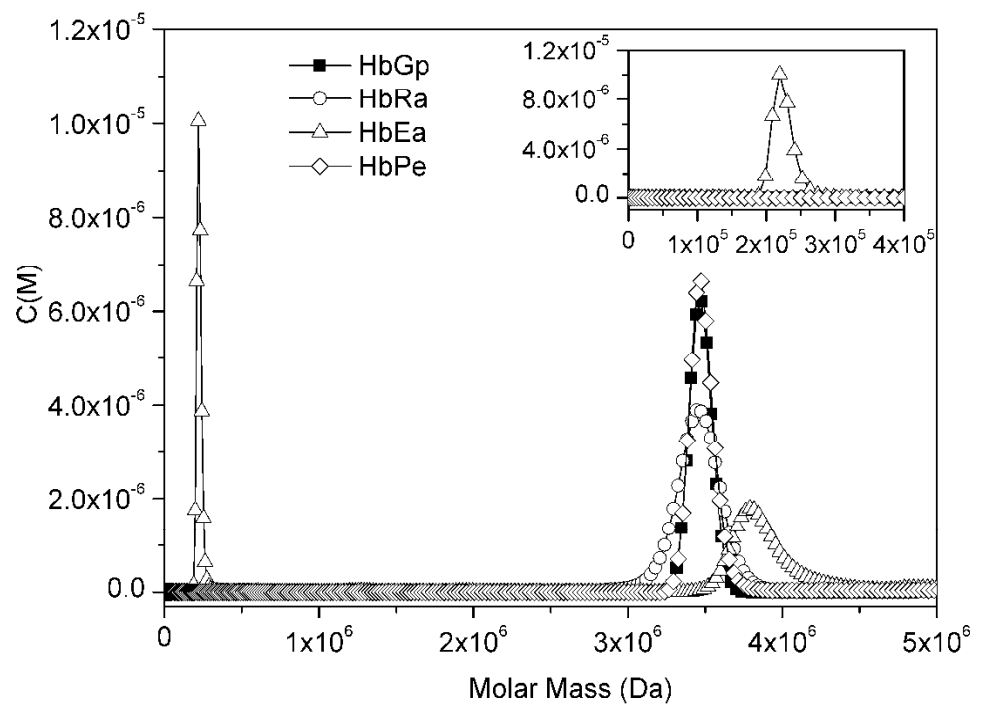

Fig. 5. Continuous molecular mass distribution of extracellular hemoglobins. The c(M) fittings for hemoglobins, at a concentration of $300 \mu \mathrm{g} / \mathrm{mL}$, in $100 \mathrm{mmol} / \mathrm{L}$ Tris- $\mathrm{HCl}$ containing $50 \mathrm{mmol} / \mathrm{L} \mathrm{NaCl}$ are shown. The insert shows the enhanced plot in the $M M$ range from 0 to $400 \mathrm{kDa}$. The $M M$ for each fitted curve was determined as the maximum of the peaks of $\mathrm{c}(\mathrm{M})$ curves. Absorbance was monitored at $415 \mathrm{~nm}$. 
In the $\mathrm{c}(\mathrm{M})$ distribution curve for the hemoglobin of Eisenia andrei an additional species of $210 \mathrm{kDa}$ is observed, which is assigned to the dodecamer $(a b c d)_{3}$. This mass value is in agreement with the literature reports of $205 \mathrm{kDa}$ [19]. Moreover, the peak at $3.8 \mathrm{MDa}$ corresponding to the whole native protein is broadened, which is, probably, due to a superposition of two contributions: from species lacking the dodecamer and from the whole protein.

The $M M$ of three of the hemoglobins shown in Table 4 is around $3.6 \mathrm{MDa}$, indicating that these proteins have the same stoichiometry and subunits with quite similar mass. Moreover, these $M M$ values strongly suggest that the Vinogradov's model [ $\left.(a b c d)_{3} L_{3}\right]_{12}$ [19] is adequate for the hemoglobins of Glossoscolex paulistus, $\mathrm{HbGp}$, Rhinodrilus alatus, $\mathrm{HbRa}$, and Perionyx excavatus, HbPe. However, our results indicate that for the hemoglobin of Eisenia andrei this model is not appropriate, since a significant mass difference is observed corresponding to 12 additional linker chains (with an average mass of $27 \mathrm{kDa}$ ).

\subsection{Structural model and stoichiometry}

The first crystallization experiments with giant hemoglobins are dated from 1840, when crystals from HbLt were obtained. Indeed, HbLt was the first protein crystallized ever [40]. Nevertheless, it took more than one hundred and sixty years to obtain a complete crystallographic structure [20]. The crystal structure of HbLt, at $3.5 \AA$ of resolution, elucidated how the hierarchical levels of an erythrocruorin is made, and represented a fundamental step to better understand these structures. Recently, our group, reported the preliminary structure of HbGp, at $3.15 \AA$ of resolution [21]. The HbGp and HbLt share an estimated identity for the monomer subunit $d$ of $54 \%$ [41], with the HbGp structure showing the same hierarchical levels as HbLt (Fig. 6), and the same global association, into type 1 . It was the second time that an entire type 1 erythrocrurin has been reported. As in $\mathrm{HbLt}$, the electron density map of the HbGp reveals important details, such as the conserved calcium biding sites, inter/intra chains disulfide bonds and heme group positions. Very recently, crystals from the giant hemoglobins from $\mathrm{HbEa}$, and $\mathrm{HbPe}$ were also obtained in our group and the preliminary structure for $\mathrm{HbEa}$ has been solved, with a resolution of 4.7 $\AA$, which is enough to conclude that, like $\mathrm{HbGp}$ and $\mathrm{HbLt}, \mathrm{HbEa}$ also belongs to type 1 array. Further experiments are needed to improve the resolution and find evidences on the electron density map where $\mathrm{HbEa}$ shows an accumulation of mass [42].

Another very recent relevant advance in the structural analysis was the characterization of the isolated subunit $d$ from HbGp. In the biological unit, subunits type $d$ form an interface with subunits type $a$, involving the heme groups from both chains, and at the same time an interface with two other subunits $d$, forming a trimeric array, as shown in Fig. 6. We showed that once isolated, the subunit $d$ shows, as a first level of aggregation, a dimer $d$ - $d$, with an interface involving heme groups, similar to the one observed between $a$ - $d$ in the biological unit (where $a$ and $d$ shares $27 \%$ of identity). In the next level, the crystal lattice shows a stable dimer of dimers $d$ - $d$. This tetrameric array is unrelated with the hetero tetramer $(a b c d)$ in the biological unit [43]. The existence of these oligomeric structures has also been confirmed by AUC, which shows that the pure monomer $d$ solution contains also three species, monomer, dimer and tetramer, and increasing the protein concentration the contribution of the monomeric species reduces from 90 to $80 \%$ [44]. On the other hand, the trimer formed by the subunits $d$ in the biological unit has not been observed for the isolated 
subunit $d$, which leads us to conclude that such an arrangement is a consequence of associations between subunits $d$ and $a$ in the whole oligomer.
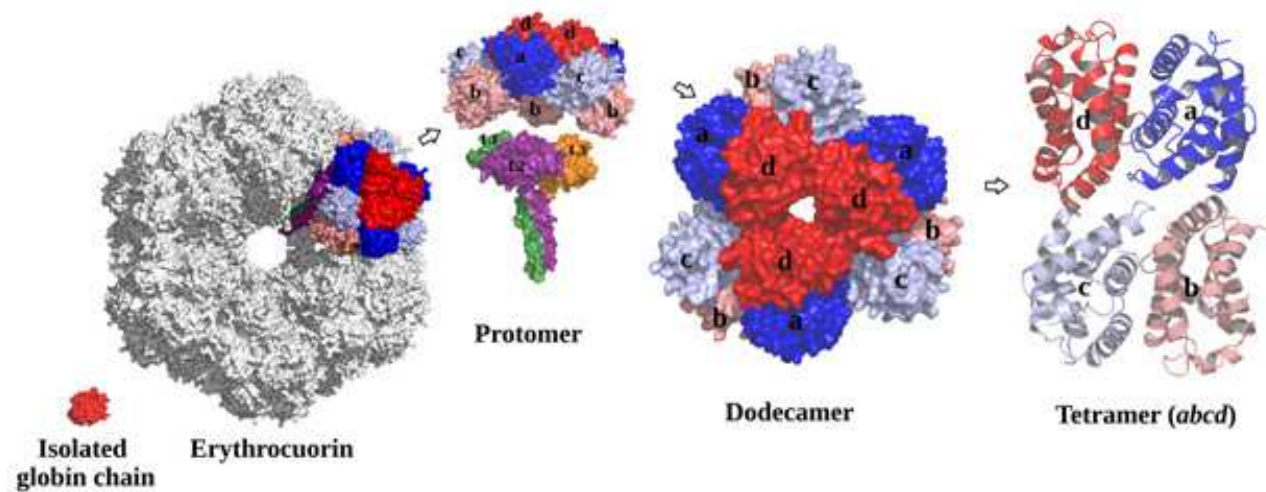

Fig. 6. Schematic representation of the hierarchy in the oligomeric assembly of $\mathrm{HbGp}$ into the native structure as obtained from crystallographic data analysis. The whole HbGp structure is composed by twelve protomers, each of them containing a dodecameric structure of globins and three linker subunits, $(a b c d)_{3} L_{3}$. The dodecameric structure is composed by four types of globin chains: $a, b, c$ and $d$. The four globin chains are associated as a hetero-tetramer (where $a, b$, and $c$ form a trimer, linked by disulfide bonds).

\section{Conclusions}

In order to evaluate the potential usefulness of such a giant protein such as $\mathrm{HbGp}$ for biomedical applications, a detailed knowledge of its constituent subunits is very relevant. In the present review chapter, recent results for $\mathrm{HbGp}$ were described, based on the use of SDS-PAGE, MALDI-TOF-MS and AUC. Preliminary characterization of three new extracellular hemoglobins of different worm species was also described for the first time. The electrophoresis analysis of these hemoglobins shows that they have a subunits structure very similar to that described for HbGp. Moreover, our present results based on AUC data show that two of the new hemoglobins have a total MM similar to that of HbGp, namely 3.6 $\mathrm{MDa}$, while the fourth one has a higher MM of 3.8 MDa. It appears clear from our data that the globin chains are a total of four with a trimer of $52-53 \mathrm{kDa}$ and a monomer of $16 \mathrm{kDa}$ as a common feature for all these hemoglobins. The highest $M M$ hemoglobin, HbEa, has heavier linker chains as well as one of the globin monomers. MALDI-TOF-MS analysis for $\mathrm{HbGp}$ showed that the monomer $c$ presents four isoforms and that the trimer, $a b c$, is characterized by two isoforms, $T_{1}$ and $T_{2}$. In the final part of this review some crystal structures are also reported, which might be helpful in understanding the oligomeric structure of this class of proteins. Our present studies for HbGp are consistent with literature reports on several other extracellular hemoglobins, such as the HbLt and $\mathrm{HbAm}$. Future more detailed characterization of the new hemoglobins will be important to assess all the subunit masses to model their oligomeric structure. We believe our results represent a nice contribution and an important and necessary step in the complete characterization of HbGp oligomeric structure. 


\section{Acknowledgments}

Thanks are due to the Brazilian agencies FAPESP, CNPq, and CAPES for partial financial support. P.S. Santiago is grateful to FAPESP and CNPq for postdoctoral grants. F. A. O. Carvalho is the recipient of a PhD. grant from FAPESP (2009/17261-6). J. W. P. Carvalho is the recipient of a PhD. grant from FAPESP (2010/09719-0). M. Tabak is grateful to CNPq for a research grant. Thanks are also due to Mr. Ézer Biazin for efficient support in the sample preparations and size exclusion chromatography experiments. The authors are indebted to Prof. Paolo di Mascio from Instituto de Química, Universidade de São Paulo, São Paulo, for making available the MALDI-TOF-MS instrumentation and to Mrs. Izaura N. Toma for excellent technical support in the experiments. The authors are greatful to Prof. Richard Garrat and Mr. Fernando Maluf, from the Instituto de Física de São Carlos, University of São Paulo, São Carlos, Brazil, respectively, for constant interest on the crystal structure analysis and support with purification of $\mathrm{HbEa}$ and $\mathrm{HbPe}$. Thanks are also due to Mr. Afrânio Augusto Guimarães, from Minhobox (www.minhobox.com.br) for making available Eisenia andrei and Peryonix excavatus worms.

\section{References}

[1] Vinogradov, S.N. (2004). The stoichiometry of the four linker subunits of Lumbricus terrestris hemoglobin suggests an asymmetric distribution. Micron, Vol.35, No. 1-2, (January-February 2004), pp. 127-129, ISSN 0968-4328.

[2] Weber, R.E; Vinogradov, S.N. (2001). Nonvertebrate hemoglobins: functions and molecular adaptations. Physiological Reviews, Vol. 81 No. 2, (April 2001), pp. 569628, ISSN 0031-9333.

[3] Carvalho, F.A.O; Santiago, P.S; Borges, J.C; Tabak, M. (2008). On the molecular mass of the extracellular hemoglobin of Glossoscolex paulistus: Analytical ultracentrifugation reexamination. Analytical Biochemistry, Vol. 385, No. 2, (February 2009), pp. 257-263, ISSN 0003-2697.

[4] Ohtsuki, M; Crewe, A.V. (1983). Evidence for a central substructure in a Lumbricus terrestris hemoglobin obtained with stem low-dose and digital processing techniques. Journal of ultrastructure Research. Vol. 83, No. 3, (1983), pp. 312-318, ISSN 0022-5320.

[5] Weber, R.E; Fago, A. (2004). Functional adaptation and its molecular basis in vertebrate hemoglobins, neuroglobins and cytoglobins Respiratory Physiology $\mathcal{E}$ Neurobiology. Vol. 144, No.2-3, (December 2004), pp. 141-159, ISSN 1569-9048.

[6] Rousselot, M; Delpy, E; La Rochelle, C.D; Lagente, V; Pirow, R; Rees, J; Hagege, A; Le Guen, D; Hourdez, S; Zal, F. (2006). Arenicola marina extracellular hemoglobin: a new promising blood substitute. Biotechnology Journal. Vol. 1, No.3, (March, 2006), pp. 333-345, ISSN 1860-7314.

[7] Zhu, H; Ownby, D.W; Riggs, C.K; Nolasco, N.J; Stoops, J. K; Riggs, A. F. (1996). Assembly of the gigantic hemoglobin of the earthworm Lumbricus terrestris - Roles of subunit equilibria, non-globin linker chains, and valence of the heme iron. Journal of Biological Chemistry. Vol. 271, No. 47, (June, 1996), pp. 30007-30021, ISSN 0021-9258. 
[8] Fushitani, K; Riggs. A. F. (1991). The extracellular hemoglobin of the earthworm Lumbricus terrestris-oxygenation properties of isolated chains, trimer, and reassociated products. Journal of Biological Chemistry. Vol. 266, No. 16, ( June, 1991), pp. 10275-10281, ISSN 0021-9258.

[9] Hirsch, R.E; Jelicks, L.A; Wittenberg, B.A; Kaul, D.K; Shear, H.L; Harrington. J.P. (1997). A first evaluation of the natural high molecular weight polymeric Lumbricus terrestris hemoglobin as an oxygen carrier. Artificial Cells Blood Substitutes and Immobilization Biotchnoplogy. Vol. 25, No. 5, (1997) 429-444, ISSN 1073-1199.

[10] Harnois, T; Rousselot, M; Rogniaux, H; Zal, F. (2009). High-level Production of Recombinant Arenicola Marina Globin Chains in Escherichia Coli: A New Generation of Blood Substitute. Artificial Cells Blood Substitutes and Immobilization Biotchnoplogy. Vol. 37, No. 3, (2009), pp. 106-116, ISSN 1073-1199.

[11] Royer, W.E; Sharma, H; Strand, K; Knapp, J.E; Bhyravbhatla, B. (2006). Lumbricus Erythrocruorin at $3.5 \AA$ Resolution: Architecture of a Megadalton Respiratory Complex. Structure. Vol. 14, No. 7, (May, 2006), pp. 1167-1177, ISSN 0969-2126.

[12] Martin, P.D; Kuchumov, A; Green, B.R; Oliver, R.W.A; Braswell, E.H; Wall, J.S; Vinogradov, S.N. (1996). Mass spectrometric composition and molecular mass of Lumbricus terrestris hemoglobin: A refined model of its quaternary structure. Journal of Molecular Biology. Vol. 255, No.1, (January,1996), pp. 154-169, ISSN 00222836.

[13] Viana, E; Silva, C.H.T.P; Tabak, M; Imasato, H; and Garrat, R.C. (1998). A molecular model for the $\mathrm{d}$ chain of the giant haemoglobin from Lumbricus terrestris and its implications for subunit assembly. Biochimical et Biophysical Acta-Protein Structure and Molecular Enzymology. Vol. 1383, No.1, (March, 1998), pp. 130-142, ISSN 01674838 .

[14] Ownby, D.W.; Zhu, H.; Schneider, K.; Beavis, R.C.; Chait, B.T.; Riggs, A.F. (1993). The extracellular hemoglobin of the earthworm Lumbricus terrestris-determination of subunit stoichiometry. Journal of Biological Chemistry. Vol. 268, No. 18, (June, 1993), pp. 13539-13547, ISSN 0021-9258.

[15] Oliveira, M.S; Moreira, L.M; Tabak, M. (2007). Partial characterization of giant extracellular hemoglobin of Glossoscolex paulistus: A MALDI-TOF-MS study. International Journal of Biological Macromolecules. Vol. 40, No. 5, (April 2007), pp. 429436, ISSN 0141-8130.

[16] Svedberg, T; Inga-Britta, E. (1933). The molecular weight of erythrocruorin. Journal of the American Chemical Society. Vol. 55, No. 7, (May-August, 1933), pp. 2834-2841, ISSN 0002-7863.

[17] Daniel, E.; Lustig, A.; David, M.M.; Tsfadia. Y. On the molecular mass of Lumbricus erythrocruorin. Micron, Vol. 35, No.1-2, (2004), pp. 131-132, ISSN 0968-4328.

[18] Daniel, E; Lustig, A; David, M.M; Tsfadia, Y. (2003). Towards a resolution of the longstanding controversy regarding the molecular mass of extracellular erythrocruorin of the earthworm Lumbricus terrestris. Biochimica et Biophysica Acta-Protein and Proteomics. Vol. 1649, No. 1, (June 2003), pp. 1-15, ISSN 1570-9639. 
[19] Vinogradov, S.N; Lugo, S; Mainwaring, M.G; Kapp, O.H; Crewe, A.V. (1986). Bracelet Protein: A Quaternary Structure Proposed for the Giant Extracellular Hemoglobin of Lumbricus terrestris. Proceeding of the Academy of Sciences of the United States of America. Vol. 83, No. 21, (November 1986), pp. 8034-8038, ISSN 0027-8424.

[20] Royer, W.E; Strand, K; Van Heel. M; Hendrickson, W.A. (2000). Structural hierarchy in erythrocruorin, the giant respiratory assemblage of annelids. Proceedings of the National Academy of Science of the United States of America. Vol. 97, No.13, (June, 2000) 7107-7111, ISSN 0027-8424.

[21] Bachega, J.F.R; Bleicher, L; Horjales, E.R; Santiago, P.S; Garratt, R.C; Tabak M. (2011). Crystallization and preliminary structural analysis of the giant haemoglobin from Glossoscolex paulistus at 3.2 angstrom. Journal of Synchrotron Radiation, Vol. 18, (January 2011), pp. 24-28, ISSN 0909-0495.

[22] Zal, F; Green, B.N; Martineau, P; Lallier, FH; Toulmond, A; Vinogradov, S.N; Childress, J.J. (2000). Polypeptide chain composition diversity of hexagonalbilayer haemoglobins within a single family of annelids, the Alvinellidae. European Journal of Biochemistry. Vol. 267, No. 16, (August 2000), pp. 5227-5236, ISSN 0014-2956.

[23] Zal, F; Green, N; Lallier, F.H; Vinogradov S.N; Toulmond, A. (1997). Quaternary structure of the extracellular haemoglobin of the lugworm Arenicola marina: a multiangle-laser-light-scattering and electrospray-ionisation-mass-spectrometry analysis. European Journal of Biochemistry, Vol. 243, No. 1-2, (January 1997), pp. 85-92, ISSN 0014-2956.

[24] Royer, W.E, Omartian, M.N, Knapp, J.E. (2007). Low resolution structure of Arenicola erythrocruorin: Influence of coiled coils on the architecture of a megadalton respiratory protein. Journal of Molecular Biology, Vol. 365, No. 1, (January 2007), pp. 226-236, ISSN 0022-2836.

[25] Rousselot, M; Le Guen, D; Chabasse, C; Zal, F. (2006). Novel dissociation mechanism of a polychaetous annelid extracellular haemoglobin. FEBS Journal, Vol. 273, No. 7 (April 2006), pp. 1582-1596, ISSN 1742-464X.

[26] Santiago, P.S; Moura, F; Moreira, L.M; Domingues, M.M; Santos, N.C; Tabak, M. (2008). Dynamic light scattering and optical absorption spectroscopy study of $\mathrm{pH}$ and temperature stabilities of the extracellular hemoglobin of Glossoscolex paulistus. Biophysical Journal, Vol. 94, No. 6, (March 2008), pp. 2228-2240, ISSN 0006-3495.

[27] Agustinho, S.C.M; Tinto, M.H; Imasato, H; Tominaga, T.T; Perussi, J.R; Tabak, M. (1996). Spectroscopic studies of the met form of the extracellular hemoglobin from Glossoscolex paulistus. Biochimica et Biophysica Acta (BBA) - Protein Structure and Molecular Enzymology, Vol. 1298, No. 2, (December 1996), pp. 148-158, ISSN 01674838 .

[28] Bispo, J.A.C; Santos, J.L.R; Landini, G.F; Goncalves, J.M; Bonafe, C.F.S. (2007). PH dependence of the dissociation of multimeric hemoglobin probed by high hydrostatic pressure. Biophysical Chemistry, Vol. 125, No. 2-3, (February 2007), pp. 341-349, ISSN 0301-4622. 
[29] Righi, G. (1971). Sobre a família Glossoscolecidae (Oligochaeta) no Brasil. Arquivos de Zoologia S. Paulo 20, Vol. 29, pp. 1-95, ISSN 0066-7870 (in Portuguese).

[30] Righi, G. (1972). Bionomic Considerations Upon Glossoscolecidae (Oligochaeta). Pedobiologia, Vol. 12, No. 4, pp. 254-260, ISSN 0031-4056.

[31] Maboeta, M.S; Reinecke, A.J; Reinecke, S.A. (1999). Effects of Low Levels of Lead on Growth and Reproduction of the Asian Earthworm Perionyx excavatus (Oligochaeta). Ecotoxicology and Environmental Safety, Vol. 44, No. 3, (November 1999), pp. 236-240, ISSN 0147-6513.

[32] Edwards, C.A, Dominguez, J, Neuhauser, E.F. (1998). Growth and reproduction of Perionyx excavatus (Perr.) (Megascolecidae) as factors in organic waste management. Biology and Fertility of Soils. Vol. 27, No. 2, (June 1998), pp.155-161, ISSN 0178-2762.

[33] Buch, A.C. (2010). Pontoscolex Corethrurus (Müller, 1857) e Eisenia Andrei, Bouché 1972, Como Bioindicadoras De Solos Contaminados por Agrotóxicos. Universidade Federal do Paraná, Curitiba-Brazil (in Portuguese).

[34] Vampré, T.M; Fuccillo, R; de Andréa, M.M. (2010). Oligoqueta Eisenia Andrei Como Bioindicador De Contaminação De Solo Por Hexaclorobenzeno(1). Revista Brasileira de Ciência do Solo, Vol. 34, No. 1, pp. 59-66, ISSN 0100-0683

[35] Cortez, J; Billes, G; Bouché, M.B. (2000). Effect of climate, soil type and earthworm activity on nitrogen transfer from a nitrogen-15-labelled decomposing material under field conditions. Biology and Fertility of Soils, Vol. 30, No. 4, (January 2000), pp. 318-327, ISSN 0178-2762.

[36] Sautter, K.D; Brown, G.G; James, S.W; Pasini, A; Nunes, D.H; Benito, N.P. (2006). Present knowledge on earthworm biodiversity in the State of Paraná, Brazil. European Journal of Soil Biology, Vol. 42, No. 42, (August 2006), pp. S296-S300, ISSN 1164-5563.

[37] Carvalho, F.A.O; Santiago, P.S; Borges, J.C; Tabak, M. (2011). Molecular masses and sedimentation coefficients of extracellular hemoglobin of Glossoscolex paulistus: Alkaline oligomeric dissociation. International Journal of Biological Macromolecules, Vol. 48, No. 1, (January 2011), pp. 183-193, ISSN 0141-8130.

[38] Carvalho, F.A.O; Carvalho, J.W.P; Santiago, P.S; Tabak, M. (2011). Further characterization of the subunits of the giant extracellular hemoglobin of Glossoscolex paulistus (HbGp) by SDS-PAGE electrophoresis and MALDI-TOF-MS. Process Biochemistry, Vol.46 (August 2011), pp. 2144-2151.

[39] Krebs, A; Kuchumov, A.R; Sharma, P.K; Braswell, E.H; Zipper, P; Weber, R.E; Chottard, G; Vinogradov, S.N. (1996). Journal of Biological Chemistry, Vol. 271, No. 31, (August 1996), pp. 18695-18704, ISSN 0021-9258

[40] McPherson, A. (1999) Crystallization of Biological Macromolecules. Cold Spring Harbor Lab. Press, Plain view, NY.

[41] Cabral, B.C; Imasato, H; Rosa, JC; Laure, H.J; da Silva, C.H; Tabak, M; Garratt, R.C; Greene, L.J. (2002). Fluorescence properties of tryptophan residues in the monomeric $d$-chain of Glossoscolex paulistus hemoglobin: an interpretation based on a comparative molecular model. Biophysical Chemistry, Vol. 97, No. 2-3, (June 2002), pp. 139-157, ISSN 0301-4622 
[42] Bachega, J.F.R et al, work in progress.

[43] Bachega JFR, Horjales ER, Tabak M, Garratt RC. (2011). Preliminary Crystallographic Structure of Subunit D from the Giant Hemoglobin of Glossoscolex paulistus. XL Reunião Anualda Sociedade Brasileira de Bioquímica e Biologia Molecular - SBBq. No. M54, pp. 76

[44] Bachega, J.F.R et al., manuscript in preparation. 


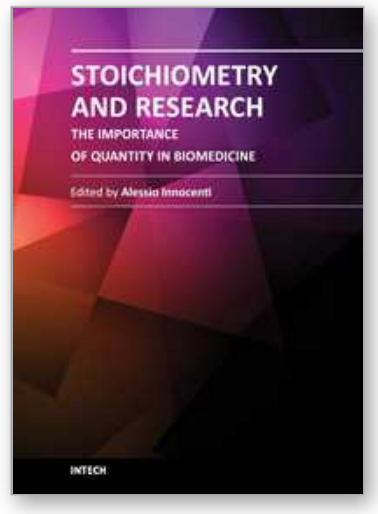

\section{Stoichiometry and Research - The Importance of Quantity in Biomedicine}

Edited by Dr Alessio Innocenti

ISBN 978-953-51-0198-7

Hard cover, 376 pages

Publisher InTech

Published online 07, March, 2012

Published in print edition March, 2012

The aim of this book is to provide an overview of the importance of stoichiometry in the biomedical field. It proposes a collection of selected research articles and reviews which provide up-to-date information related to stoichiometry at various levels. The first section deals with host-guest chemistry, focusing on selected calixarenes, cyclodextrins and crown ethers derivatives. In the second and third sections the book presents some issues concerning stoichiometry of metal complexes and lipids and polymers architecture. The fourth section aims to clarify the role of stoichiometry in the determination of protein interactions, while in the fifth section some selected experimental techniques applied to specific systems are introduced. The last section of the book is an attempt at showing some interesting connections between biomedicine and the environment, introducing the concept of biological stoichiometry. On this basis, the present volume would definitely be an ideal source of scientific information to researchers and scientists involved in biomedicine, biochemistry and other areas involving stoichiometry evaluation.

\section{How to reference}

In order to correctly reference this scholarly work, feel free to copy and paste the following:

Marcel Tabak, Francisco A.O. Carvalho, José W.P. Carvalho, Jose F.R. Bachega and Patrícia S. Santiago (2012). Recent New Characterizations on the Giant Extracellular Hemoglobin of Glossoscolex paulistus and Some Other Giant Hemoglobins from Different Worms, Stoichiometry and Research - The Importance of Quantity in Biomedicine, Dr Alessio Innocenti (Ed.), ISBN: 978-953-51-0198-7, InTech, Available from: http://www.intechopen.com/books/stoichiometry-and-research-the-importance-of-quantity-inbiomedicine/recent-new-characterizations-on-the-giant-extracellular-hemoglobin-of-glossoscolex-paulistusand-som

\section{INTECH}

open science | open minds

\author{
InTech Europe \\ University Campus STeP Ri \\ Slavka Krautzeka 83/A \\ 51000 Rijeka, Croatia \\ Phone: +385 (51) 770447 \\ Fax: +385 (51) 686166 \\ www.intechopen.com
}

\author{
InTech China \\ Unit 405, Office Block, Hotel Equatorial Shanghai \\ No.65, Yan An Road (West), Shanghai, 200040, China \\ 中国上海市延安西路65号上海国际贵都大饭店办公楼 405 单元 \\ Phone: +86-21-62489820 \\ Fax: +86-21-62489821
}


(C) 2012 The Author(s). Licensee IntechOpen. This is an open access article distributed under the terms of the Creative Commons Attribution 3.0 License, which permits unrestricted use, distribution, and reproduction in any medium, provided the original work is properly cited. 